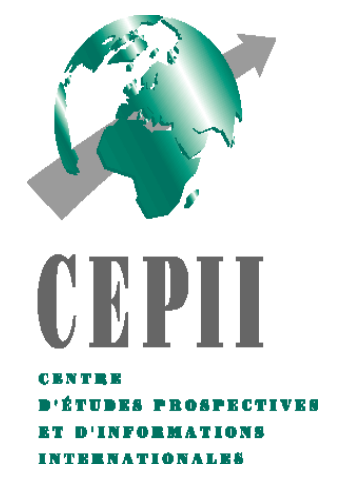

No 1996 - 14

December

Growth and Agglomeration

Philippe Martin

Gianmarco Ottaviano 


\section{TABLE OF CONTENTS}

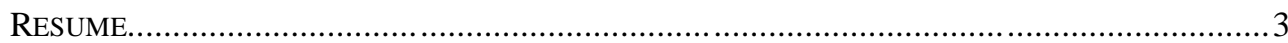

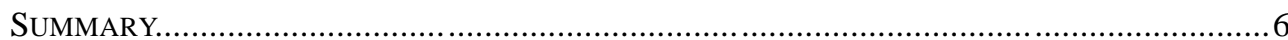

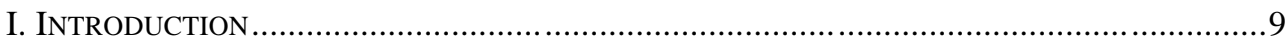

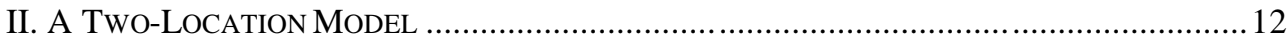

IV. GROWTH AS A FUNCTION OF ECONOMIC GEOGRAPHY............................................ 17

V. UNSTABLE ANDSTABLE EQUILIBRIA............................................................ 19

VI. GROWTH, AGGLOMERATION AND TRADE......................................................25

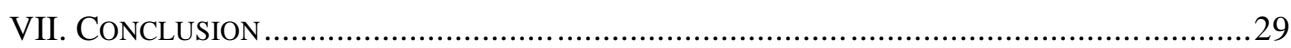

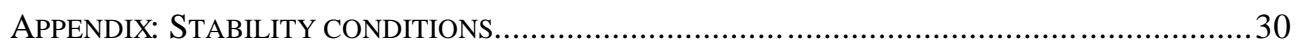

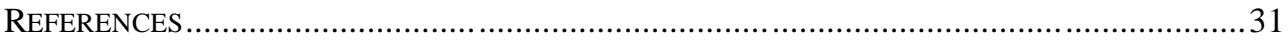

LIST OF WORKING PAPERS RELEASED B YCEPII ...................................................... 33 


\section{RESUME}

Nous partons de deux faits stylisés : (i) la corrélation positive entre le phénomène d'agglomération spatiale et la croissance économique ; (ii) la ressemblance forte entre la géographie de la production et celle de l'innovation.

La première observation a été abondamment soulignée par les historiens de l'économie, et par les économistes spécialistes du développement et de la croissance. Historiquement, la révolution industrielle en Europe est marquée par la hausse du taux de croissance ainsi que par celle du taux d'urbanisation. Celui-ci (mesuré par le pourcentage d'habitants dans les villes de plus de 5000 habitants), a crû en moyenne de $0,07 \%$ par an au XVIII ${ }^{\text {ème }}$ siècle, puis de $1,1 \%$ au XIX ${ }^{\text {ème }}$ siècle. Au cours de la même période, les taux de croissance de la production ont été multipliés par trois. Les données historiques rassemblées par Kuznet illustrent le poids croissant de la population urbaine qui a accompagné le développement de nombreux pays riches. Cette relation entre croissance et agglomération implique également que les pays plus riches se distinguent par un degré d'urbanisation plus élevé. Effectivement, une analyse en coupe sur 95 pays montre une corrélation positive très forte entre le niveau d'urbanisation et le log du PNB par tête. Au cours de ces dernières années, ce sont les pays en croissance rapide de l'Asie de l'Est qui ont enregistré l'augmentation la plus forte des taux d'urbanisation. A titre d'exemple, en Chine, dans la foulée des réformes libéralisant l'économie, le taux d'urbanisation est passé de $17,9 \%$ en 1978 à 53,9\% en 1990. L'agglomération des activités économiques ne se concrétise pas uniquement par la croissance du taux d'urbanisation. En Chine, où la politique officielle consiste à empêcher les migrations campagne-villes, la concentration se traduit aussi depuis les réformes par une disparité croissante dans le développement entre les provinces côtières et celles de l'intérieur. Ainsi, alors que les villes côtières ne représentaient en 1991 que 2,5\% de la population chinoise, elles ont réalisé 8,6\% du PIB et reçu $36 \%$ de l'investissement direct étranger. Au cours de cette période d'agglomération spatiale accélérée, la croissance a progressé à un rythme annuel de 8,1\%.

La corrélation entre croissance et agglomération n'est donc pas en doute, c'est un fait stylisé de la croissance. Cependant, dans tous ces cas, se pose le problème de "la poule et de l'oeuf". Est-ce la croissance qui induit l'agglomération ? Ou l'inverse ? Ou bien la causalité fonctionne-t-elle dans les deux sens?

Le deuxième fait stylisé a été bien mis en évidence par le rôle des villes dans la croissance de l'économie et du progrès technique qui a été souligné tant par les économistes de l'urbanisme que par les spécialistes de la croissance. Des travaux empiriques récents montrent que l'innovation tend à se rassembler là où l'activité productive se concentre, et que les activités d'innovation sont géographiquement plus concentrés que les activités de production. La Silicon Valley, dans le secteur informatique, en est une illustration.

Dans ce document, nous présentons un modèle qui intègre ces deux faits stylisés, et qui illustre certains des mécanismes économiques qui leur sont sous-jacents. L'idée centrale est de modéliser la croissance et l'agglomération géographique comme des processus qui se renforcent mutuellement de telle sorte qu'il existe une causalité circulaire 
entre les deux phénomènes : la croissance engendre l'agglomération géographique qui renforce elle-même la croissance. Si le secteur à l'origine de l'innovation et de la croissance (appelé ici secteur R\&D) utilise comme inputs des biens achetés à des industries non compétitives, alors, du fait de la présence d'économies d'échelle, ces industries vont se localiser là où se trouve le secteur à la source de la croissance. Quand celle-ci s'accélère, le secteur innovant se développe et un nombre croissant de firmes vont s'implanter près des activités innovantes : ceci génère un «forward linkage » dans le vocabulaire de la « nouvelle géographie ». Du fait des coûts de transaction, les coûts de l'innovation en cet endroit diminuent et l'incitation à innover s'accentue, de telle sorte que la croissance s'accélère : cela correspond à un «backward linkage ». Le mécanisme à l'oeuvre derrière cette relation croissance-agglomération ne repose pas sur des externalités locales mais seulement sur des externalités pécuniaires.

La logique de ce modèle s'appuie sur certaines idées communément admises par la "nouvelle géographie économique" qui souligne la présence de mécanismes de causalité circulaire pour expliquer la concentration spatiale des activités économiques et les phénomènes de divergence. Dans ces modèles, les mécanismes qui permettent à des forces centripètes (celles qui sont à l'origine de l'agglomération) de l'emporter sur les forces centrifuges (celles qui entraînent la dispersion), proviennent soit des migrations de travailleurs, soit de la présence de liens verticaux intra-sectoriels.

Notre modèle donne une troisième explication au phénomène de concentration spatiale, à savoir la croissance des activités économiques. Nous partons d'une situation où deux localisations sont identiques et nous montrons que lorsque l'économie commence à croître, le seul équilibre stable est celui où une des localisations bénéficie de toutes les innovations et de la plupart des activités de production. En fusionnant un modèle de nouvelle géographie économique avec un modèle de croissance endogène, nous mettons en évidence non seulement un nouveau facteur explicatif de la concentration, mais aussi le rôle déterminant dans la croissance économique de la répartition géographique des activités économiques : l'agglomération engendre une divergence dans les niveaux de revenu entre les régions, mais accélère aussi le taux de croissance de l'ensemble de l'économie.

Nous montrons également qu'aussi longtemps que l'économie stagne (taux de croissance à zéro), aucun mécanisme d'agglomération ne joue. Quand sont levés les obstacles à la croissance, à travers par exemple un accroissement de la taille du marché ou une baisse des coûts de transaction, alors les deux taux, celui de la croissance et celui de l'urbanisation, augmentent, ces deux phénomènes se renforçant l'un l'autre.

Une interprétation possible de notre modèle est que le lien où l'innovation et la plupart des industries se localisent est une ville. Dans notre modèle, l'apparition et la croissance des villes sont à la fois la cause et la conséquence de l'innovation et de la croissance. Le modèle est centré sur le rôle des métropoles urbaines vers où convergent la production et les innovations technologiques, ainsi que la croissance. En cela, notre modèle étudie aussi l'apparition de phénomènes type Silicon Valley. 
Une autre conséquence de ce modèle est que des coûts de transaction plus faibles dans une économie accroissent le taux d'innovation dans l'ensemble de l'économie, à travers un effet de localisation des activités. Une raison en est que lorsque les coûts de transaction se réduisent, le coût du secteur à l'origine de l'innovation diminue aussi. Ceci induit de nouvelles innovations. La deuxième raison est que lorsque les coûts de commerce baissent, les firmes se redéploient vers le marché le plus vaste qui est celui où l'activité innovante est importante. Ceci, à nouveau, diminue le coût de l'innovation puisque d'avantage de biens n'ont pas besoin d'être importés de l'autre localisation. Ces deux effets se renforcent mutuellement du fait du mécanisme de causalité circulaire. 


\section{SUMMARY}

We start from two stylized facts: (i) the positive correlation between agglomeration and growth of economic activities; (ii) the strong resemblance between the geography of production and the geography of innovation.

The first fact is strongly emphasized by economic historians, development economists and economists of growth. Historically, the period of the industrial revolution in Europe is characterized both by the increase of the growth rates and by an increase of the urbanization rate. The urbanization rate in Europe (the percentage of inhabitants in cities of more than 5000) increased by an average $0.07 \%$ per year during the eighteenth century while it increased by $1.1 \%$ per year during the nineteenth century. The growth rates of production were multiplied by 3 during the same period. Kuznet historical data document the increased share of population living in urban areas during the phase of economic development of a number of rich nations. This relation between growth and agglomeration also implies that richer countries have typically a higher level of urbanization. Indeed, on a cross section of 95 countries, there is a very strong positive correlation between the level of urbanization and the log of GNP per capita. Finally, in recent years, the fast growing East Asian countries have experienced the fastest rates of urbanization. For example, following reforms, China's urbanization rate increased from $17.9 \%$ in 1978 to $53.9 \%$ in 1990 . Agglomeration of economic activities does not only take the form of a rise in the urbanization rate. In China, where the official policy is to prevent rural-urban migration, it also materialized itself in the growing economic disparity between coastal and inland provinces since the reforms. For example, even though coastal cities only represented $2.5 \%$ of the Chinese population, they accounted for $8.6 \%$ of total GDP and received 36\% of foreign direct investment in 1991. During this period of increasing spatial agglomeration of economic activities, the economy grew by an annual average of $8.1 \%$ per year

The correlation between growth and agglomeration is not in question; in fact it is a stylized fact of growth. However, in all these cases, a "chicken and egg" problem arises. It is not obvious whether growth spurred agglomeration or the other way around or whether causality runs both ways.

The second stylized fact is best illustrated by the role of cities in economic growth and technological progress that has been emphasized by urban economists as well as by economists of growth. Recent empirical work has shown that innovative activity tends to cluster where production activities concentrate and that innovative activity is more spatially concentrated than production itself. Silicon Valley for the computer industry represents an example of this.

In this paper, we construct a model which is consistent with these two stylized facts and illustrates some of the economic mechanisms behind them. The main idea is to model growth and geographic agglomeration as mutually self-reinforcing processes so that circular causality arises between growth and agglomeration: growth brings spatial agglomeration which itself fosters growth. If the sector at the origin of innovation and 
growth (which we call the R\&D sector in our model) uses goods from imperfectly competitive industries as inputs, then, because of increasing returns, these industries will be drawn towards the location where the sector at the origin of growth operates. When growth increases the innovation sector expands and more firms relocate where innovation activities are located: this gives us a «forward linkage». Because of the presence of transaction costs, this in turn lowers the cost of innovation in this location and bolsters the incentive to innovate so that the growth rate increases: this corresponds to the idea of a «backward linkage ». The mechanism at work behind the growth-agglomeration relation does not require localized externalities and is based only on pecuniary externalities.

The logic of the model borrows some common features from the "new economic geography" which focuses on the presence of circular causation mechanisms to explain the spatial concentration of economic activities. In these models, the economic mechanisms that allow centripetal forces (the forces at the origin of spatial concentration) to overcome the centrifugal forces (the forces at the origin of dispersion) come either from the migration of workers or from the presence of intra-sectoral vertical linkages.

Our model shows a third way along which agglomeration can occur, namely through growth of economic activities. We start from an initial situation where two locations are identical and show that when the economy starts growing, the only stable equilibrium is one in which one of the two locations gets all the innovation activity and most of the industrial production. By merging a new economic geography model into an endogenous growth model, we are able not only to identify a new determinant of agglomeration, but also to give to the spatial distribution of economic activities an important role in explaining growth: agglomeration generates divergence in income levels between regions but it also increases the growth rate of the whole economy.

We also show that as long as the economy is stagnating (the growth rate is zero), then no agglomeration mechanism takes place. When the impediment to growth is eliminated, for example through an increase in the market size or a decrease of transaction costs, then both the growth rate and the rate of agglomeration can increase and these phenomena reinforce each other.

A natural interpretation of our model is that the location where innovation activities and most of industries are located is a city. In our model, the emergence of cities is both the consequence and the cause of innovation and growth. The model focuses on the role of metropolitan areas as centers both of production activities and of technological innovations and growth. In this sense, our model also analyses the emergence of Silicon Valleys types of phenomena.

Another implication of the model is that lower transaction costs in an economy increases, through an effect on the location of economic activities, the rate of innovation in the whole economy. The first reason is that as transaction costs go down, the cost of the sector at the origin of innovation also goes down. This spurs new innovations. The second reason is that as trade costs go down firms relocate towards the largest market which is where innovation activities are performed. This again decreases the cost of 
innovation as less of the goods are imported from the other location. These two effects reinforce each other because of the circular causation mechanism at work. 


\title{
GROWTH AND AGGLOMERATION
}

\author{
Philippe Martin? \\ Gianmarco I P Ottaviand
}

\section{INTRODUCTION}

Spatial agglomeration of economic activities on the one hand and economic growth on the other hand are parallel processes. Historically, the period of the industrial revolution in Europe is characterized both by the increase of the growth rates and by an increase of the urbanization rate. The urbanization rate in Europe (the percentage of inhabitants in cities of more than 5000) as defined by Bairoch (1988) increased by an average $0.07 \%$ per year during the eighteenth century while it increased by $1.1 \%$ per year during the nineteenth century. The growth rates of production were multiplied by 3 during the same period. The strong positive correlation between growth and geographic agglomeration of economic activities has been documented by economic historians (Hohenberg and Lees, 1985 for example). The role of cities in economic growth and technological progress has been emphasized by urban economists (Henderson, 1988, Fujita and Thisse, 1996), development economists (see Williamson, 1988 on the urban transition) as well as by economists of growth (Kuznet, 1966, and Lucas, 1988). Kuznet historical data document the increased share of population living in urban areas during the phase of economic development of a number of rich nations. In a very long term view this relation between growth and agglomeration also implies that richer countries should typically have a higher level of urbanization. This correlation is illustrated by chart 1 which plots the level of urbanization against the log of the GNP per capita in 1990 for a cross section of 95 countries. Finally, in the recent years, the fast growing East Asian countries also have had the fastest rates of urbanization. For example, following reforms, China's urbanization rate increased from $17.9 \%$ in 1978 to $53,9 \%$ in 19904 . Agglomeration of economic activities does not only take the form of a rise in the urbanization rate. In China, where the official policy is to prevent rural-urban migration,

\footnotetext{
${ }^{1}$ We thank Richard Baldwin, Antonio Ciccone, Harry Flam, Gordon Hanson and Elhanan Helpman for helpful discussions on the subject of this paper. We have also benefited from comments at seminars at the Institute for International Economic Studies in Stockholm and the Graduate Institute of International Studies in Geneva and at the CEPR workshop in Louvain-la-Neuve on "Location and regional Convergence/Divergence". We are responsible for any remaining mistake. Ottaviano gratefully acknowledges funding from the Swiss National Science Foundation (n.831-048782).

2 Graduate Institute of International Studies (Geneva), CEPII (Paris) and CEPR (London)

${ }^{3}$ Università di Bologna - CESPRI (Milan) and CEPR (London)

$4 \mathrm{Wu}$ (1994) argues that due to definition problems these numbers overestimate the «urban transition » but still estimates that after two decades of stagnation, the urbanization rate increased from $14,8 \%$ in 1978 to $22 \%$ in 1990
} 
it also materialized itself in the growing economic disparity between coastal and inland provinces since the reforms. For example, even though coastal cities only represented $2.5 \%$ of the Chinese population, they accounted for $8.6 \%$ of total GDP and received $36 \%$ of foreign direct investment in 1991. During this period of increasing spatial agglomeration of economic activities, the economy grew by an annual average of $8.1 \%$ per year.

Chart 1: GNP per capita and urbanization, 1990

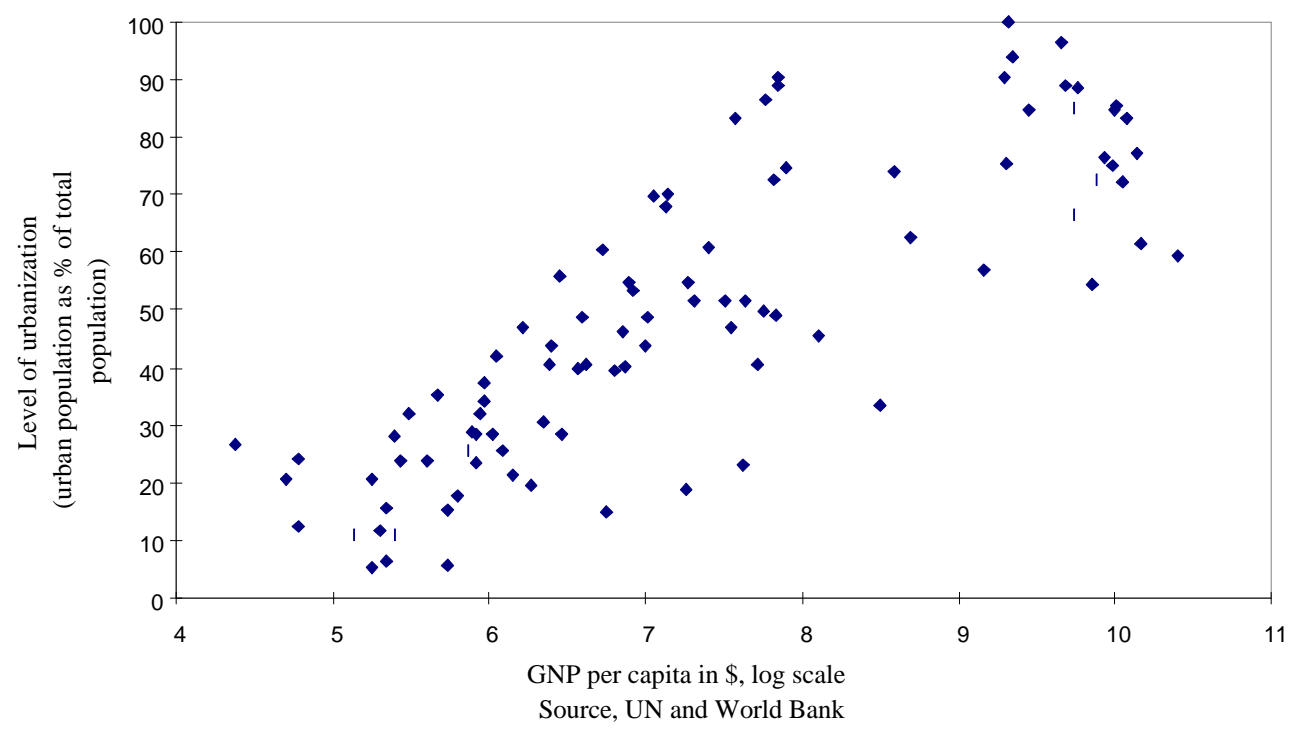

In all the cases that we have mentioned so far, a "chicken and egg" problem arises as it is not obvious whether growth spurred agglomeration or the other way around. In this paper, we construct a model which is consistent with the correlation and show how growth and geographic agglomeration are mutually self-reinforcing processes. Growth, through innovation, spurs agglomeration of economic activities which in turn leads to a lower cost of innovation and higher growth so that a circular causation between growth and the geographic concentration of economic activities sets in. More precisely, if the sector at the origin of innovation and growth (which we call the R\&D sector in our model) uses goods from imperfectly competitive industries as inputs, then these industries will be drawn towards the location where the R\&D sector operates: this gives us a « forward linkage ». Because of the presence of transaction costs, this in turn lowers the cost of R\&D and increases the incentive to innovate and the growth rate which corresponds to the idea of a «backward linkage».

The logic of the model borrows some common features from the "new economic geography" which focuses on the presence of circular causation mechanisms to explain the spatial concentration of economic activities (Krugman, 1991a and b, Venables 1996). In these models, the centripetal forces come from preference for variety on the consumption 
side (Krugman's models) or diversity in intermediate goods on the production side (Venables model). The centrifugal forces arise from the pressure posed by geographic concentration on local factor markets that bids up prices. When transport costs are low enough, a process of agglomeration sets in. In Krugman's models an increasing returns sector uses a specific input so that, in order to relax the pressure on its local input market, mobility between locations is allowed ${ }^{5}$. In Venables's model there is no specificity in the input used by the increasing returns sector. The pressure can thus be alleviated without inter-locational mobility. All that is required is inter-sectoral mobility in the presence of intra-sectoral vertical linkages in the increasing returns sector.

Our model shows a third way along which agglomeration can occur. On purpose, we isolate the model from the occurrence of both Krugman's and Venables's agglomeration processes. We allow neither inter-locational mobility of inputs nor intra-sectoral vertical linkages in the manufacturing sector. Under these circumstances, in the usual static setting of the new geography models no cumulative causation would set in. We show that this is not true anymore if growth is introduced. In order to do so, we build in the model an endogenous process of innovation and growth along the lines of Romer (1990) and Grossman and Helpman (1991). The introduction of technological progress and growth generates the cumulative process that leads to geographic agglomeration. We start from an initial situation where both locations are identical and show that as long as the economy is growing, the only stable equilibrium is one in which one of the two locations gets all the innovation activity and most of the industrial production.

We are able not only to identify a new determinant of agglomeration, but also to give to spatial distribution of economic activities an important role in explaining growth. As in Krugman's models agglomeration generates spatial divergence in income levels. In addition, we show that the more spatially agglomerated an economy is the faster it grows.

A first step in that direction is made in Martin and Ottaviano (1996) who show how localized spillovers in R\&D can be at the origin of an increasing relation between economic concentration of economic activities and growth. In that paper, no agglomeration mechanism existed however because growth did not influence the concentration of economic activities. The originality of the present paper lies in the introduction of a circular causation mechanism which relies on growth and which furthermore does not rely on any localized technological externalities. The forces behind agglomeration and growth are local market interactions and pecuniary externalities between firms and laboratories as well as intertemporal - as opposed to local technological spillovers.

A natural interpretation of our model is that the location where innovation activities and most of industries are located is a city. The emergence of cities and the process of agglomeration is both the consequence and the cause of growth. The model focuses on the

5 In that same family of models, Englmann and Walz (1995) show that with non traded intermediates and interregional factor mobility, production and innovation activities tend to cluster in the region with an initial advantage in the number of intermediates. 
role of metropolitan areas as centers both of production activities and of technological innovations and growth. In this sense, our model also analyses the emergence of Silicon Valleys types of phenomena. It is also consistent with the empirical evidence by Audretsch and Feldman (1996) who show that the geography of innovation and the geography of production tend to mirror each other even though imperfectly.

Section II. of the paper presents the general framework of the model. In section III., we derive the equilibrium relation that illustrates the demand linkage at work in the model and makes geography of economic activities a function of the growth rate. Section IV. derives the cost linkage that makes the growth rate a function of the geography. Section $\mathrm{V}$. puts these two relations together to show that an initial situation where both locations are identical is not a stable equilibrium and that the only stable equilibrium is one where all the R\&D activity and most of production activities are agglomerated in one location. Section V. looks how changes in parameters, especially transaction costs, modify the growth/geography joint equilibrium.

\section{A Two-LocationModeL}

The model merges a location framework which is a variant of Krugman (1991) and Venables (1996) and a growth framework similar to Romer (1990) and Grossman and Helpman (1991). There are two initially identical locations called location 1 and location 2. Variables referring to location 2 are labeled by *. Each location is endowed with a fixed amount $\mathrm{L}$ of labor which we assume to be immobile between locations so as to abstract from that particular agglomeration channel. Labor can be used to produce a homogenous good and differentiated goods which are aggregated into a composite good. All goods are final consumption goods. Moreover, the composite good can be used as intermediate input in the R\&D sector to create new varieties of the composite good itself. The invention of a new variety is protected by a patent which can then be sold to any producer located in either location. The innovation and the production processes are therefore conducted by different economic agents and possibly in different locations.

Since the model is symmetric, we concentrate on the specification of location 1 . Preferences are instantaneously nested-C.E.S. and intertemporally C.E.S. with unit elasticity of intertemporal substitution:

$$
\mathrm{U}=\int_{0}^{\infty} \log \left[\mathrm{D}(\mathrm{t})^{\alpha} \mathrm{Y}(\mathrm{t})^{1-\alpha}\right] \mathrm{e}^{-\rho \mathrm{t}} \mathrm{dt}
$$

where $\mathrm{Y}$ is the consumption of the homogeneous good (an agricultural good for example), $\rho$ is the rate of time preference, and $\alpha \in(0,1)$ is the share of expenditures devoted to D, a composite manufactured good which, following Dixit and Stiglitz (1977), consists of a number of different varieties: 
$D(t)=\left[\sum_{i=1}^{N(t)} D_{i}(t)^{1-1 / \sigma}\right]^{1 /(1-1 / \sigma)} \quad \sigma>1$

where $\mathrm{N}$ is the total number of varieties available in the economy. Growth will come from an increase in the variety of products measured by N. $\sigma$ is the elasticity of substitution between varieties as well as the own-price elasticity of demand for each variety.

The value, in terms of the numeraire $\mathrm{Y}$, of expenditure $\mathrm{E}$ is:

$E=\sum_{i=1}^{n} p_{i} D_{i}+\sum_{j=n+1}^{N} \tau p_{j}^{*} D_{j}+Y$

where $\mathrm{n}$ is the number of goods of the maufacturing sector produced in location 1 and $\mathrm{N}=\mathrm{n}+\mathrm{n}^{*}$. As in Samuelson (1954) and in the economic geography literature, transaction costs in the form of iceberg costs have been introduced. $\tau$ is more than 1 so that only a fraction of the good purchased in the other location is actually consumed. As it is common in the new geography models, there is no transaction cost for the numeraire good which is introduced to tie down the wage rate.

As to the supply side, the homogenous good is produced using only labor with constant returns to scale in a perfectly competitive sector. Without loss of generality, the input requirement is set to 1 for convenience. Moreover it is assumed that the demand of this good in the whole economy is large enough that it cannot be satisfied by production in one location only. This hypothesis ensures that in equilibrium the homogenous good will be produced in both locations. Hence, because of free trade, the wage rates in the two locations will be equalized. In addition, the assumption of unit input requirement and the choice of $\mathrm{Y}$ as the numeraire pins down the wage rate to 1 everywhere.

The differentiated good is produced in a monopolistically competitive sector which can be interpreted as the manufacturing sector. The production of each variety exhibits increasing returns to scale. Together with the assumption of costless differentiation this ensures that each firm will produce only its own variety. More precisely, the supply of one unit of each variety requires the services of one patent (the fixed cost at the source of economies of $\operatorname{scale}^{6}$ ) and $\beta$ units of labor. Under these assumptions, optimal pricing for any variety gives producer prices $\mathrm{p}=\mathrm{p}^{*}=\beta \sigma /(\sigma-1)$. The operating profits of a producer using a patent are revenues minus the labor costs:

$$
\mathrm{p}=\mathrm{px}-\beta \mathrm{x}=\frac{\beta \mathrm{x}}{\sigma-1}
$$

where $\mathrm{x}$ is the optimal output/size of a typical firm in equilibrium.

\footnotetext{
${ }^{6}$ This way of introducing economies of scale has been used in Flam and Helpman (1987) and Martin and Rogers (1995).
} 
The invention of new varieties which is at the source of growth in the model is performed in a sector which we call the R\&D sector. This sector produces ideas that it can patent and then sells these patents in both locations to producers who need a patent to start the production of differentiated goods. Alternatively, we could assume that research is performed by firms themselves which then use the invention they have developed to start production. They would be free to locate the production process in either location and then repatriate the profits. The value of the patent would in that interpretation be the value of the firm and a stockmarket would replace the market for patents. This alternative legal framework used in Martin and Rogers (1995) and Martin and Ottaviano (1996) would generate the exact same results.

No transaction cost hinders the trade in patents and the R\&D sector is perfectly competitive. The process of innovation requires the composite good D as the only input with an input requirement $\eta \mu$. The use of intermediates in R\&D is closely related to Rivera-Batiz and Romer (1991) and Baldwin and Forslid (1996). Given that we assume the same elasticity of substitution $\sigma$ between varieties for consumers and for the R\&D sector the cost for developing a new variety in location 1 is $F=[\beta \sigma /(\sigma-1)]\left[n z_{i}+n^{*} \tau z_{j}\right]$ where $z_{i}$ and $z_{j}$ are the demands for the differentiated goods produced in location 1 and location 2 respectively. The problem of a researcher is therefore to minimize this cost subject to the input requirement constraint:

$$
\eta \mu \quad \mathrm{nz}_{\mathrm{i}} / \sigma \quad \mathrm{n}^{*} \mathrm{z}_{\mathrm{j}} / \sigma \overline{/ \sigma}
$$

Solving for the demands of each variety by a single researcher in location 1 , we find

$$
\mathrm{z}_{\mathrm{i}} \quad \eta \mu\left(\mathrm{n}+\mathrm{n}^{*} \delta\right)^{\frac{\sigma}{\sigma}} ; \mathrm{z}_{\mathrm{j}} \quad \eta \mu \tau^{-\sigma}\left(\mathrm{n}+\mathrm{n}^{*} \delta\right)^{\frac{\sigma}{\sigma}}
$$

where $\delta \equiv \tau^{1-\sigma} \in(0,1)$. The equilibrium cost of R\&D is then:

$$
\mathrm{F}=\frac{\beta \sigma}{\sigma-1} \eta \mu \mathrm{N}^{\frac{1}{1-\sigma}}[\gamma+(1-\gamma) \delta]^{\frac{1}{1-\sigma}}
$$

where $\gamma=\mathrm{n} / \mathrm{N}$ is the share of varieties produced in location 1 and is less or equal to 1. $\gamma$ will be a crucial parameter of the model as it will measure the extent of agglomeration of the manufacturing sector in location 1. Equation (7) builds a pecuniary externality into the model. The cost of innovation is lower in the location where there are more local firms since, in the presence of transaction costs, the C.E.S. aggregate used for R\&D costs less. This is an example of what is sometimes called a "vertical linkage" in the new economic geography literature (e.g. Venables, 1996). Moreover, for a given value of $\mu$, which measures the extent of technological spillovers necessary for a constant growth rate (see section IV), the cost of R\&D decreases as new differentiated goods are invented (i.e. as $\mathrm{N}$ 
increases) because these differentiated goods are used as specialized inputs in the R\&D sector.

The equilibrium cost of $R \& D$ in location 2 is symmetric:

$\mathrm{F}^{*}=\frac{\beta \sigma}{\sigma-1} \eta \mu \mathrm{N}^{\frac{1}{1-\sigma}}[1-\gamma+\gamma \delta]^{\frac{1}{1-\sigma}}$

As the goods produced by the R\&D sector, which is perfectly competitive, are costlessly tradable between the two locations, the price and the cost of R\&D have to be the same in equilibrium for both locations to engage in R\&D. This immediately implies that $\mathrm{R} \& \mathrm{D}$ is split between the two locations only if $\gamma=1 / 2$, i.e. if the manufacturing sector is also perfectly split. If $\mathrm{F}<\mathrm{F}^{*}$, then all $\mathrm{R} \& \mathrm{D}$ is conducted in location 1 and vice-versa.

Finally, we assume that a safe asset exists that bears an interest rate $r$ in units of the numeraire. Its market is characterized by free financial movements between the two locations. The intertemporal optimization by consumers then implies that the growth rate of expenditure is equal to the difference between the interest rate and the rate of time preference: $\hat{\mathrm{E}}=\hat{\mathrm{E}}^{*}=\mathrm{r}-\rho$. It will turn out that in equilibrium $\mathrm{E}$ and $\mathrm{E}^{*}$ are constant so that $r=\rho$.

A steady state of the model is defined as an equilibrium where $\gamma$, the proportion of firms in location 1 , is constant and the number of varieties grows at a constant rate

$\mathrm{g}=\dot{\mathrm{N}} / \mathrm{N}$. Thus, the solution of the model will be fully characterized by the equilibrium location $\gamma$ and the steady growth rate of innovation g. Due to its perfect symmetry, we know that the model will have at least a symmetric solution in which both locations engage in $R \& D$ and the production of the two goods is evenly split between them $(\gamma=0.5)$. We claim and will prove that (i) this is not the only equilibrium of the model since there are two other equilibria in which a single location engages in R\&D and is (partially) specialized in the supply of the differentiated goods $(\gamma<0.5$ and $\gamma>0.5)$; (ii) while the symmetric equilibrium is unstable, the other two equilibria are stable since a slight perturbation does not destroy them.

\section{Economic geography as a function of growth}

In this section, we characterize the equilibrium condition for the location of firms. We consider the two possible equilibria: one where the R\&D is split between the two locations and one where R\&D takes place in a single location, say in location 1. By symmetry, mutatis mutandis, all the findings would carry through if location 2 were the only one to perform R\&D. Several equilibrium conditions characterize the steady state location and growth rates. The first is a market clearing condition for the manufacturing sector: if $\mathrm{R} \& \mathrm{D}$ is concentrated in location 1 , this condition implies that the supply of each variety equals demand (inclusive of transaction costs) from consumers in both locations as well as demand from R\&D labs in location 1: 


$$
\begin{aligned}
& x=\frac{\alpha L(\sigma-1)}{\beta \sigma}\left(\frac{E}{N[\gamma+(1-\gamma) \delta]}+\frac{E^{*} \delta}{N[\delta \gamma+(1-\gamma)]}\right)+\frac{\sigma-1}{\beta \sigma} \frac{F \dot{N}}{N[\gamma+(1-\gamma) \delta]} \\
& x^{*}=\frac{\alpha L(\sigma-1)}{\beta \sigma}\left(\frac{E \delta}{N[\gamma+(1-\gamma) \delta]}+\frac{E^{*}}{N[\delta \gamma+(1-\gamma)]}\right)+\frac{\sigma-1}{\beta \sigma} \frac{F \dot{N} \delta}{N[\gamma+(1-\gamma) \delta]}
\end{aligned}
$$

In the above equations, on the right hand side the first term gives the usual demands by consumers derived from utility maximization. The second term is the demand from the R\&D labs $\left(z_{i}\right.$ and $z_{j}$ in equation 6$)$ multiplied by the number of new inventions per unit of time $(\dot{N})$.

If both locations engage in R\&D in equilibrium, so that in equations (8a) and (8b) demands from the R\&D sector in location 2 are added, the supply-equal-demand conditions are replaced by:

$$
\begin{aligned}
& x=\frac{\alpha L(\sigma-1)}{\beta \sigma}\left(\frac{E}{N[\gamma+(1-\gamma) \delta]}+\frac{E^{*} \delta}{N[\delta \gamma+(1-\gamma)]}\right)+\frac{\sigma-1}{2 \beta \sigma}\left[\frac{F \dot{N}}{N[\gamma+(1-\gamma) \delta]}+\frac{F \dot{N} \delta}{N[1-\gamma+\gamma \delta]}\right] \\
& x^{*}=\frac{\alpha L(\sigma-1)}{\beta \sigma}\left(\frac{E \delta}{N[\gamma+(1-\gamma) \delta]}+\frac{E^{*}}{N[\delta \gamma+(1-\gamma)]}\right)+\frac{\sigma-1}{2 \beta \sigma}\left[\frac{F \dot{N} \delta}{N[\gamma+(1-\gamma) \delta]}+\frac{F \dot{N}}{N[1-\gamma+\gamma \delta]}\right]
\end{aligned}
$$

Because of free trade in patents, the profits and therefore the optimal size of the firms are the same across locations, so that $\mathrm{x}=\mathrm{x}^{*}$. This equilibrium condition which insures that firms have no incentive to relocate in equilibrium, implies that we can solve (8a) and ( $8 b)$ for $\gamma$ in the case where R\&D is concentrated in location 1 :

$$
\gamma=\frac{\alpha L\left(E-E^{*} \delta\right)+g N F}{(1-\delta)\left[\alpha L\left(E+E^{*}\right)+g N F\right]}
$$

where $\mathrm{g}=\dot{N} / N$ is the growth rate of the economy. This equation illustrates the forward linkage at work in our model implying that geographic agglomeration increases with growth, which manifests itself by an increased activity in the R\&D sector. It has the usual interpretation that firms in the manufacturing sector will tend to locate in the region which has the highest expenditure level. Here, the novelty comes from the fact that expenditures on the differentiated goods comes not only from consumers but also from the R\&D sector. It can already be seen that in the case where R\&D is agglomerated in one location, a higher growth rate implies a higher demand for the differentiated goods which gives an incentive for firms to move to that location $\gamma$ increases with $\mathrm{g}$.

If $R \& D$ is split between the two locations then the location of industries is given by: 
$\gamma=\frac{\alpha \mathrm{L}\left(\mathrm{E}-\mathrm{E}^{*} \delta\right)+(1-\delta) \mathrm{gNF}}{(1-\delta)\left[\alpha \mathrm{L}\left(\mathrm{E}+\mathrm{E}^{*}\right)+2 \mathrm{gNF}\right]}$ in this case.

implying $\gamma=0.5$ as expected for $\mathrm{E}=\mathrm{E}^{*}$ which is so as the two locations are identical

Whatever the location of $R \& D$ and of the manufacturing sector, the size of firms is

$\mathrm{x}=\frac{\sigma-1}{\beta \sigma}\left[\alpha \mathrm{L} \frac{\mathrm{E}+\mathrm{E}^{*}}{\mathrm{~N}}+\mathrm{Fg}\right]$

We have found two possible equilibrium locations: one is given by equation (9a) in the case when location 1 is the only one to have R\&D activities, the other one is given by equation (9b) which tells us that if $R \& D$ activities are perfectly split then so too will be the industrial activities.

\section{GROWTH AS A FUNCTION OF ECONOMIC GEOGRAPHY}

We now need to turn to the intertemporal equilibrium. Calling $\mathrm{v}$ the value of a patent, the condition of no arbitrage opportunity between patents and the safe asset implies:

$\mathrm{r}=\frac{\dot{\mathrm{v}}}{\mathrm{v}}+\frac{\pi}{\mathrm{V}}$

On an investment on a patent of value $\mathrm{v}$, the return is equal to the operating profits plus the change in the value of the patent. This condition can also be derived by stating that the equilibrium value of a patent is the discounted sum of future profits of the firm which buys the patent and has a monopoly for ever on the production of the related variety. Because of marginal cost pricing of patents, free entry and zero profits in the R\&D sector, $\mathrm{v}=\mathrm{F}$ is another equilibrium condition.

For a steady growth path to exist, it must be that the combination of the pecuniary externality and the technological spillovers is such that the cost F of doing R\&D decreases at the same rate at which operating profits of firms which buy the patents decrease. This ensures that the incentive to engage in R\&D remains constant over time. The requirement that $\mathrm{F}$ decreases at rate $\mathrm{g}$ is consistent with $\mathrm{x}$ and therefore profits decreasing at the same rate as well as with expenditures being constant (see equations 9 and 10). The parameter $\mu$ measures the technological spillovers that are required for the economy to have ongoing growth and well-defined private investment decisions in endogenous growth models ${ }^{8}$. It is

${ }^{7}$ It can be easily checked that this is also true for $\gamma=1$, i.e. full agglomeration in location 1.

8 As shown in Lucas (1988), endogenous growth models generate constant steady state growth rates only under knife-edge assumptions on parameters. Our assumption on $\mu$ is just an example of this. See Baldwin and Forslid (1996) for a similar assumption. 
picked such that a steady growth path for this economy exists: $m \equiv \mathrm{N}^{\frac{s-2}{1-s}}$ i.e. the productivity of $R \& D$, because of technological spillovers, in the two locations depends on past innovations 9 . If $\sigma$ is more than 2 , there are positive technological spillovers ( $\mu$ decreases with $\mathrm{N}$ ) so that past innovations decrease the cost of R\&D. In this case the pecuniary externality will be relatively weak as the differentiated goods are relatively good substitutes. On the contrary if $\sigma$ is between 1 and 2, there are negative technological spillovers (it becomes harder to find new innovations maybe because there is a tendency to run out of new ideas) but the pecuniary externality effect is then strong enough to compensate the negative technology spillovers. There is a specific case where intertemporal technological spillovers are not required to generate ongoing growth. All that is needed is the above mentioned pecuniary externality to be strong enough. The model will exhibit such a property for $\sigma=2$ i.e. the cost saving for R\&D due to a new variety is just enough to offset the decrease in revenues due to more competition in the differentiated good market.

The choice of $\mu \equiv \mathrm{N}^{\frac{\sigma-}{-\sigma}}$ implies that the cost of $R \& D$ is:

$\mathrm{F}=\frac{\beta \sigma}{\sigma-1} \eta \mathrm{N}^{-1}[\gamma+(1-\gamma) \delta]^{\frac{1}{1-\sigma}}$

Since FN is constant, this implies that $\dot{\mathrm{v}} / \mathrm{v}=\dot{\mathrm{F}} / \mathrm{F}=-\dot{\mathrm{N}} / \mathrm{N}=-\mathrm{g}$. Consumers' expenditures are constant (see equation $9 \mathrm{a}$ ), the interest rate $r$ is equal to the rate of time preference $\rho$. Using these results as well as (4) and (10) in (11), we find:

$g=\frac{\alpha}{\sigma-1} \frac{L\left(E+E^{*}\right)}{F N}-\rho \frac{\sigma}{\sigma-1}$

Consider now the market clearing condition in the labor market which implies that labor supply will be employed either in the agricultural sector or in the manufacturing sector:

$2 \mathrm{~L}=(1-\alpha) \mathrm{L}\left(\mathrm{E}+\mathrm{E}^{*}\right)+\beta \mathrm{Nx}$

which can be transformed when substituting for $\mathrm{x}$ in equation (10) into:

$\mathrm{E}+\mathrm{E}^{*}=2 \frac{\sigma}{\sigma-\alpha}-\frac{\sigma-1}{\sigma-\alpha} \frac{\mathrm{gNF}}{\mathrm{L}}$

\footnotetext{
${ }^{9}$ Martin and Ottaviano (1996) draw a sharp distinction between global and local R\&D spillovers. Here we do not focus on this issue and only look at the case of global spillovers. The introduction of local spillovers in R\&D would not change the qualitative nature of the equilibrium.
} 
When $R \& D$ is concentrated in location 1 , we can combine (12), (13) and (14b) to find the equilibrium growth rate that can be expressed as a function ofy only:

$$
\mathrm{g}=\frac{2 \alpha \mathrm{L}}{\eta \beta \sigma}[\gamma+\delta(1-\gamma)]^{\frac{1}{\sigma-1}}-\rho \frac{\sigma-\alpha}{\sigma-1}
$$

This equation illustrates the backward linkage at work in the model when R\&D is entirely located in location 1. An increase in the concentration of industrial activities in that location decreases the cost of $R \& D$ (because of the existence of transaction costs between the two locations) pushing new researchers to enter the R\&D sector until profits in that sector are back to zero. This in turn increases the rate of technological innovation.

In the symmetric equilibrium, growth is still given by equation (15) where $\gamma$ takes the value $1 / 2$.

To complete the solution of the model we have to determine the consumers' expenditures in the two locations, E and $\mathrm{E}^{*}$. Equations (13) and (14b) together yield:

$$
\mathrm{E}+\mathrm{E}^{*}=2+\rho \frac{\mathrm{FN}}{\mathrm{L}}
$$

The first term on the right hand side is wage income. The second is the value of the stock of patents existing initially ${ }^{10}$. Only the profits accruing to the initial stock of patents are pure rents and we assume that the two locations are initially identical. This implies that incomes and expenditures are identical in both locations ${ }^{1}$.

$$
\mathrm{E}=\mathrm{E}^{*}=1+\rho \frac{\mathrm{FN}}{2 \mathrm{~L}}
$$

Equation (17) can also be derived by noting that $\rho$ is the propensity to consume out of wealth which is FN/2L. As expenditures are constant and equal in both locations this also implies that there is no incentive for borrowing and lending between the two locations.

If location 1 gets all R\&D activities, its total GDP defined in the usual way as the sum of value added in the three sectors is: $\mathrm{GDP}_{1}=\mathrm{L}+\gamma \beta \times \mathrm{N} /(\sigma-1)$ which is higher than GDP in location 2 as $\operatorname{GDP}_{2}=\mathrm{L}+(1-\gamma) \beta \times \mathrm{N} /(\sigma-1)$ as long as $\gamma$ is more than $1 / 2$. This is because location 1 produces more differentiated goods and less constant returns to scale goods than location 2 .

\section{UNSTABLE ANDSTABLE EQUILIBRIA}

\footnotetext{
${ }^{10}$ Remember that FN is constant so that the income is fixed by the initial ownership of patents.

${ }^{11}$ However, real incomes and real expenditures differ in location 1 and location 2 because the price indexes will differ in the two locations, see section $\mathrm{V}$.
} 
We are now ready to fully describe the different equilibria of the model. Remember that the objective is to understand how, from a situation where both locations are identical, one location can emerge as the main center for both production and innovation activities, and understand how the emergence of what can be interpreted as an urban center can spur growth in the economy. We therefore want to show that the situation where both locations remain identical is an equilibrium but not a stable one when growth is positive.

The situation where both locations remain identical is a steady state equilibrium: $\gamma=$ $1 / 2$ in this case and the cost of $R \& D$ is the same in both locations so that if the economy starts in that equilibrium, there is no incentive to relocate R\&D activities. Nor is there any incentive to relocate the production of the manufacturing sector. This is because demands for the differentiated goods from the consumers and from the R\&D sectors are the same in both locations so that profits are also identical. When both locations remain identical, the growth rate is given by equation (15) wherey takes the value $1 / 2$.

However, this is not the only equilibrium. If one location (say location 1) gets more of the firms of the manufacturing sector then the cost of inputs for R\&D in that location will be lower due to the presence of transaction costs between the two locations (see equation 12). As the $R \& D$ sector is perfectly competitive and the good it produces, namely patents, freely tradable between the two locations, then this location will get all the R\&D activity and the other location will cease any innovation activity. In this case, we know that the location equilibrium is no more $\gamma=1 / 2$ but it is given by (9a) with $\gamma>1 / 2$. Using (12) and (17), we can rewrite the equilibrium location equation (9a) as:

$\mathrm{g}=\frac{(1-\delta)(2 \gamma-1) \alpha \mathrm{L}}{1-(1-\delta) \gamma}\left[\frac{\sigma-1}{\eta \beta \sigma}[\gamma+(1-\gamma) \delta]^{\frac{1}{\sigma-1}}+\frac{\rho}{2 \mathrm{~L}}\right]$

Values for $g$ and $\gamma \in(1 / 2,1]$ that satisfy both (15) and (18) are steady state solutions of the model. Equation (15) describes how the incentive to engage in R\&D and therefore the growth rate $g$ depends on the location of industries. Equation (18) gives the relation between the location of firms and the growth rate. Because of its nonlinearity in $\gamma$, it is written as the growth rate as a function of the location of industries. We deal only with interior solutions. As it can be easily checked analytically, both curves have $\mathrm{g}$ as an increasing function of $\gamma$ if $\gamma \in(1 / 2,1]$. They cross at most once in the relevant set $(\gamma, \mathrm{g})$. Graph 1 plots the two equations for a numerical example in the same diagram where equations (15) and (18) are represented respectively by the solid curve and the curve with crosses. It can be checked analytically that equation (18) is always steeper than equation (15). So, even if locations have the same initial stock of patents, a situation in which only one location performs $R \& D$ and is relatively specialized in the differentiated good, can emerge as an equilibrium. The model has thus three equilibria such that $\gamma=1 / 2, \gamma<1 / 2$ and $\gamma>1 / 2$. The equilibrium growth rate is the same no matter whether agglomeration takes place in location 1 or 2 . In these cases it is higher than in the symmetric outcome $\gamma=1 / 2$ since the cost of innovation is maximized for $\gamma=1 / 2$. 
The stability properties of the equilibria can be understood by tatonnement arguments in terms of graph 1. Equation (15) defines the locus of the pairs $(\gamma, \mathrm{g})$ such that for a given $\gamma$, growth is balanced at a rate $\mathrm{g}$ : there are zero profits in the R\&D sector. Below (15) the economy must grow faster because for this level of industrial concentration the cost of $R \& D$ is such that there are profits to be made in the R\&D sector. Above (15), the economy must grow at a lower rate because the cost of $R \& D$ is too high given the industrial concentration. Equation (18) defines the locus of the pairs $(\gamma, \mathrm{g})$, such that for a given growth rate and therefore for a given demand of the R\&D sector the profits of firms in the manufacturing sector are equal in both locations $\left(\pi=\pi^{*}\right)$ so that there is no incentive to relocate. At the left of equation (18), firms will relocate from location (2) to location (1), i.e. $\gamma$ will increase because for that level of growth the demand for differentiated goods by the R\&D sector in location 1 is high and because of increasing returns the profits of producers are higher in location 1 than in location 2 . To the right of equation (18), the growth rate is too low as well as the demand for differentiated goods by the $R \& D$ sector so that profits are higher in location 2 than in location 1: $\gamma$ has to decrease. The arrows in graph 1 are depicted accordingly so that the equilibrium with high growth and agglomeration is a stable equilibrium

Graph 1: growth and agglomeration

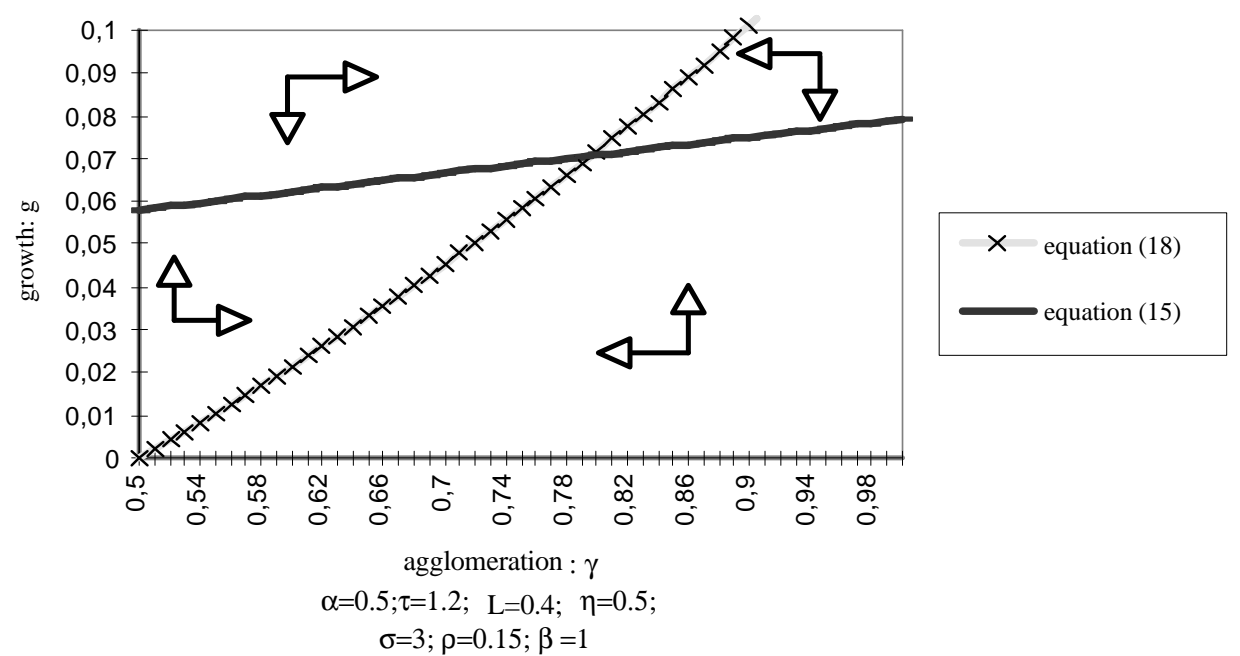

More formally, we can assess the stability of the location equilibrium by analyzing how the differential in profits between the two locations depends on $\gamma$. This requires computing the difference between $\pi$ and $\pi^{*}$ as implied by equation ( $\left.8 a-b\right)$ : if $\left(\pi-\pi^{*}\right)$ is positive then firms will move to location 1 and vice versa. For the location equilibrium to be stable, this differential must be a decreasing function of $\gamma$. The formula for $\left(\pi-\pi^{*}\right)$ is given in appendix. It is plotted as a function of $\gamma$ in graph 2 which shows that indeed the equilibrium location found in graph 1 is stable as the differential in profits between location 1 and location 2 decreases when firms move to location 1 . It also shows that $\gamma=$ $1 / 2$ is not a stable equilibrium as the differential in profits is positive as $\gamma$ goes to $1 / 2$ given 
that the $R \& D$ activities are concentrated in location 1 , which is the case when more firms are located in location 1 than in location 2.

There are also values of the parameters for which full agglomeration of economic activities in location $1(\gamma=1)$ is a stable equilibrium. They are such that the differential in profits is positive at that corner solution. For example this will be the case for low transaction costs (see appendix). Growth in the economy as well as divergence in real incomes is at its maximum in that case. We do not focus on this "core-periphery" equilibrium because we do not think it is the closest to reality where full agglomeration is rarely observed.

\section{Graph 2: stability properties}

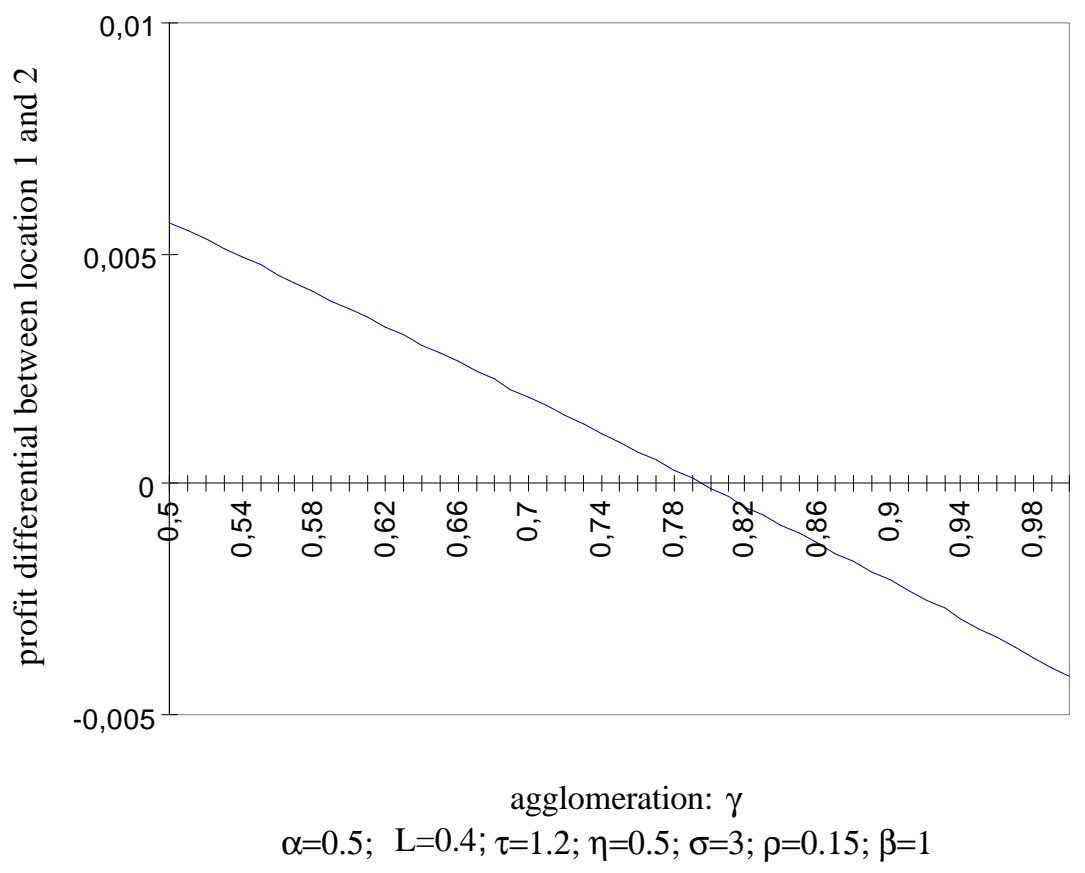

Graph 1 depicts an agglomeration cum growth story. From an initial situation of the world where both locations are identical a small disturbance will lead to both higher growth and higher agglomeration. If a firm moves from location 2 to location 1 from an initial equilibrium where $\gamma=1 / 2$ this triggers all $R \& D$ activities to move to location 1 because the cost of R\&D is now lower there. This itself triggers more firms to move to location 1 and as this lowers the cost of $\mathrm{R} \& \mathrm{D}$, the activity of that sector expands, attracting more firms until the point where there are no profits in the R\&D sector and the profits in the manufacturing sector are equalized in both locations. We can therefore interpret our agglomeration mechanism as one of the emergence of urban centers as centers of innovation and production. Silicon valley also seems to us a good illustration of our model where agglomeration and technological progress goes hand in hand. More generally it is 
consistent with experiences of rapid increases in both growth rates and spatial agglomeration.

It can also be noticed that, while the geographies of production and innovation tend to mirror each other (more firms produce where all R\&D takes place), resemblance is not perfect (production is not as fully concentrated as R\&D) which is consistent with empirical evidence (see Audretsch and Feldman, 1996). This comes from the tension between centripetal and centrifugal forces in our model. It should be clear by now that the centripetal forces rely on the vertical linkages between production and innovation: the forward linkage is the demand linkage; the backward linkage is the cost linkage. There is actually another centripetal force which builds on the relation between growth and geography. As growth and industrial concentration increase in the agglomeration process, the value of existing patents diminishes because competition becomes more fierce between the varieties of the differentiated goods. This means that when geographic concentration and growth increase, the part of incomes that comes from initially existing patents decreases. This can be seen readily by looking at equilibrium expenditures:

$\mathrm{E}=\mathrm{E}^{*}=1+\frac{\rho \beta \sigma}{\mathrm{L}(\sigma-1)} \eta \mu[\gamma+(1-\gamma) \delta]^{\frac{1}{1-\sigma}}$

Remember that incomes and therefore expenditures are the same in both locations but that industries tend to cluster in a single location because of the demand from the fully agglomerated R\&D sector. Hence, because of its negative effect on the consumers' level of income and expenditures, an increase in the rate of technological innovation increases the relative differential in market size between the two locations which further reinforces the agglomeration mechanism: it can be checked from equation (9a) that $\gamma$ is decreasing in $\mathrm{E}$ when $\mathrm{E}=\mathrm{E}^{*}$ which is the case as both locations are initially identical. The centrifugal force at the source of the result of possibly less than full agglomeration of production activities is the localized demand by immobile consumers.

We have abstracted on purpose from the possibility of migration so as to focus on growth as the channel of agglomeration. We can however easily guess what would happen if we let some or all agents move from one location to other. The price index is lower in location 1 than in location 2 because more firms produce in location 1 than in location 2 so that more goods can be bought free of transaction costs ${ }^{12}$. This readily implies in our framework that mobile workers will want to move to location 1 as real income is higher there (nominal incomes are identical, see equation 17), giving more weight to the agglomeration process because firms will also want to be close to these consumers in location 1. In this case, as more firms move to location 1 , so that the cost of R\&D decreases, growth increases due to the migration of workers in location 1 (the city).

${ }^{12}$ The price index in location 1 is: $\quad \mathrm{P}^{\alpha}=\left[\frac{\beta \sigma}{\sigma-1}\right]^{\alpha} \mathrm{N}^{\frac{\alpha}{1-\sigma}}[\gamma+\delta(1-\gamma)]^{\frac{\alpha}{1-\sigma}}$. It is lower than the symmetric price index calculated for location 2 as long as $\gamma$ is more than $1 / 2$ and it is decreasing in $\gamma$. 
The equilibrium with symmetric locations $(\gamma=1 / 2)$ can be a stable equilibrium only when the return to $R \& D$ activities is not high enough to induce growth in the economy. This will be the case for parameter values such that in equation (15) with $\gamma=1 / 2$, the right hand side is equal to or is less than zero. In this situation, the economy is stagnating because the return to innovation is too small to sustain any R\&D activity. This could be the case for example if the cost of $R \& D$ were too high, due to a high input requirement (high $\eta$ ) or to high transaction costs (high $\tau$ ). This could also be due to low operating profits in the manufacturing sector caused by a market size (L) too small to recover the cost of inventing a new variety. In all these circumstances, for which there are no incentives for technological innovations and no growth, there is no R\&D activity which implies that the mechanism behind agglomeration disappears. This can be readily seen in equation (9a) where $\gamma=1 / 2$ is the only equilibrium when $g=0$ and the return to R\&D is too low. Hence, as long as there is no technological innovation in the economy there will be no agglomeration mechanism.

However, suppose that from a situation where the economy is stagnating (zero growth) and no agglomeration process sets in, one parameter changes so that the economy starts growing. For example suppose that the market size L increases. Then, since the equilibrium with $\gamma=1 / 2$ is not stable anymore, an agglomeration process will take place reinforcing the growth process. Such a situation where an economy starts growing and at the same time experiences the emergence of a urban center as a center of innovation can be illustrated by a numerical example. Suppose that the parameters are the same as for graph 1 except for $L$ which we set at 0.3 which implies that growth is zero and $\gamma=1 / 2$ is a stable equilibrium. Then suppose that $\mathrm{L}$ increases to 0.35 . In this case the economy starts growing at rate $2.7 \%$ with $\gamma=1 / 2$. However, this is not a stable equilibrium as we have seen before and the agglomeration process sets in. The R\&D sector agglomerates in one of the two locations (say location 1) and in this case the stable equilibrium is pictured in graph 3: the steady state growth rate is $3.4 \%$ and location 1 gets almost $67 \%$ of the industrial activity in this numerical example. The increase in the growth rate and in the geographic concentration of economic activities have come together and have reinforced each other. This example is consistent again with episodes of rapid rises in growth rates coupled with increases in spatial agglomeration. 
Graph 3: From zero growth to positive growth and agglomeration $L$ goes from 0.3 to 0.35

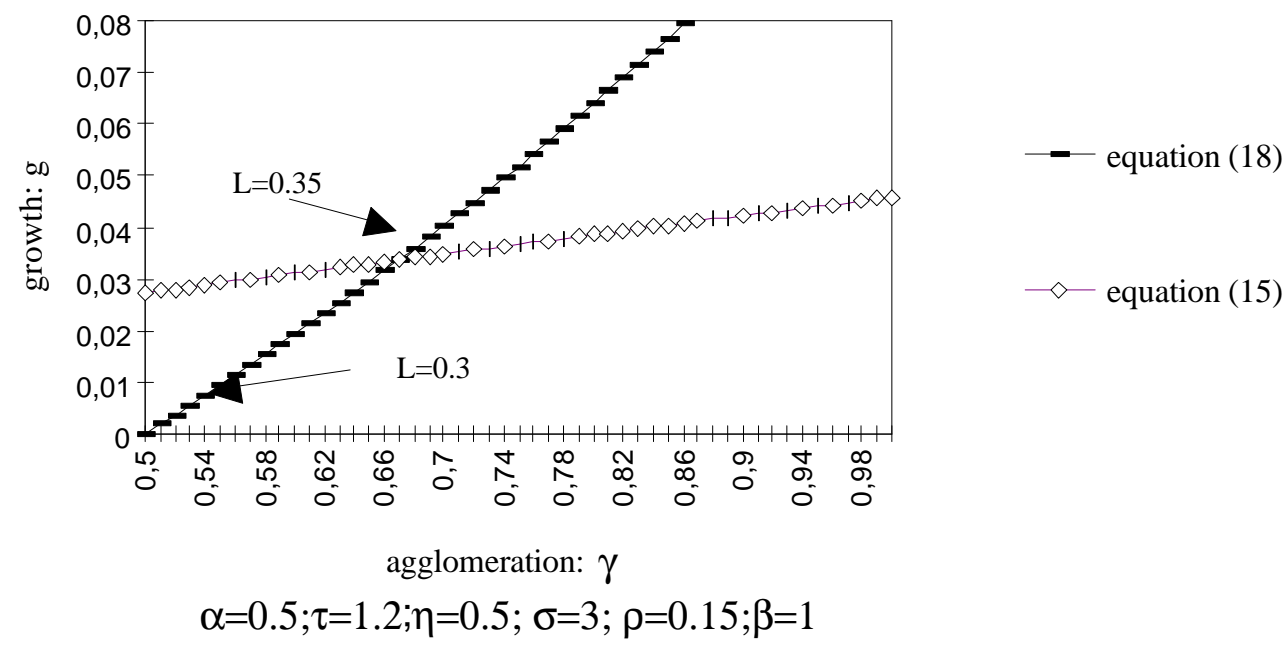

\section{GROWTH, AGGLOMERATION AND TRADE}

More insight on the behavior of the model can be gained by comparative statics. The results are shown in graph 4 . It shows the qualitative responses of the equilibrium to parameters changes. More precisely, it shows the responses to increases in each parameter while holding all the others constant at the values used in graph 1. Except for $\tau$ and $\rho$ for which the impact on $\mathrm{g}$ and $\gamma$ can also be found analytically, numerical simulations are necessary to judge the impact of changes of parameters. Growth will be faster and agglomeration stronger, the larger the market size (L) and the share of differentiated products in consumers' utility $(\alpha)$ and the smaller the labor requirement $(\beta)$, the elasticity of substitution $(\sigma)$, the transaction cost $(\tau)$, the R\&D cost $(\eta)$ and the subjective discount rate $(\rho)$.

Note that the same parameters that increase growth also increase geographic agglomeration so that a positive correlation between growth rates and agglomeration rates across economies comes naturally as a result of the model.

For example, an economy with larger market size $\mathrm{L}$ will grow faster because the operating profits of firms buying patents are higher which increases the incentive to innovate. The agglomeration will also be stronger in that economy because the expanded $R \& D$ sector attracts more firms to the location where innovation takes place.

A lower $\sigma$, the elasticity of substitution between varieties, increases the rate of innovation for a given location because monopolistic profits of the firms that buy a patent are higher when differentiation (love of variety for consumers and diversity of intermediates for the R\&D sector) is more pronounced. Stronger economies of scale ${ }^{13}$

13 In equilibrium, $\sigma /(\sigma-1)$ is the ratio of average to marginal cost. 
increase the agglomeration of economic activities for a given growth rate because the incentive to locate in the largest market is then higher. This is not a surprising result from what we know separately about the role of economies of scale from the endogenous growth literature and from the new geography literature. However, here the integration of the two models makes these two relations reinforce each other. 


\section{Graph 4: Change in parameters}
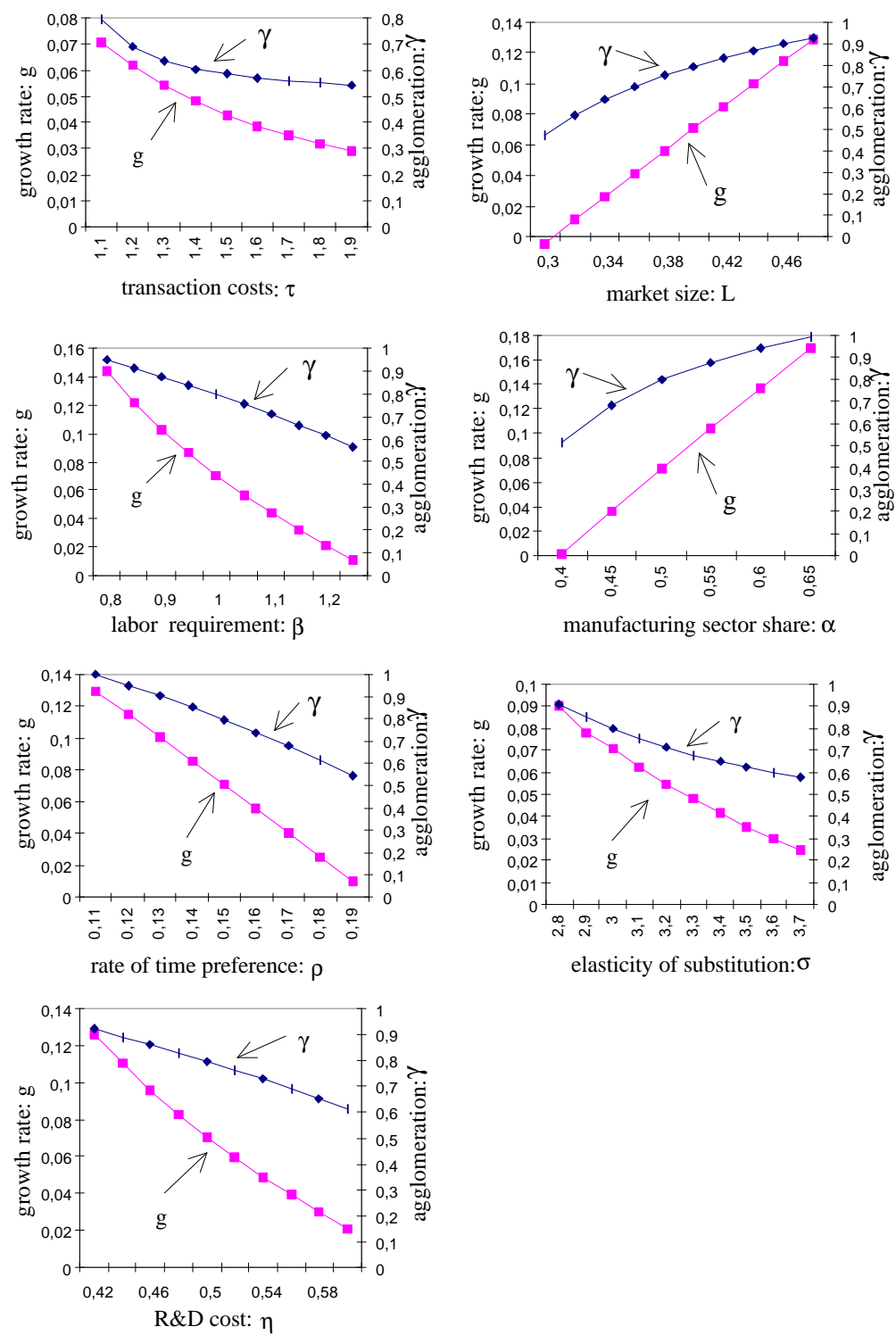

Of particular interest is also the parameter of transaction costs. A decrease in transaction costs between two regions in an economy will spur both growth and industrial concentration in the whole economy. In equation (15), the effect is clear: a decrease in transaction costs decreases the R\&D cost in location 1 , because it decreases the cost of the differentiated goods produced in location 2 . This will increase the steady state growth rate for a given location of firms. In equation (18), the location equation, the effect is less obvious because the decrease in transaction costs has three different effects on the location 
of firms. 1) a decrease in transaction costs will give an incentive for firms to move production to the location with the largest market because of increasing returns: the sensitivity of location to differences in market size differentials increases. This means that some firms move to location 1 ( $\gamma$ increases) because this is the location where all the $R \& D$ activities are located so that it is also the largest market for the differentiated goods. 2) a decrease in transaction costs also affects the market size differential between the two locations. This is because, as it has already been noted in the previous section, a decrease in transaction costs reduces the cost of innovation, increases competition, decreases the value of existing patents and therefore the consumers' income levels in both locations (see equation 19). This increases the relative importance of the R\&D sector in the economy and therefore the relative expenditure gap between the two locations which induces firms to move to location 1, i.e. $\gamma$ increases. 3) a decrease in transaction costs reduces (for a given growth rate) the input demand of the R\&D sector as less of the goods bought in location 2 melt during the transit. This last effect tends to decrease the demand for differentiated goods in location 1 and therefore tends to reduce the attractiveness of location 1. However, it can be shown analytically that this effect is always smaller than the other two effects so that, for a given growth rate, a decrease in transaction costs increases the concentration of economic activities in the location where the R\&D sector is situated.

Both the location and the growth mechanism go in the same direction. Given the circular causation this means that the effects of a decrease in transaction costs on growth and agglomeration reinforce each other. This is illustrated on graph 4 where two growth/agglomeration equilibria are shown (the same parameters are used as in graph 1) one where transaction costs are high $(\tau=1.5)$ and one they are low $(\tau=1.2)$. Equation (15) moves upwards which means that for a given location of firms, the R\&D activity is increased. Equation (18) moves to the right which means that for a given growth rate, firms will move to location 1 . In steady state, the growth rate has increased from $4.6 \%$ to $7 \%$ and, whereas in the high transaction cost equilibrium $60 \%$ of activities are concentrated in location $1,80 \%$ of them are in the low transaction costs equilibrium.

The result that a decrease in trade costs spurs growth is similar to the one in RiveraBatiz and Romer (1991), Grossman and Helpman (1991) and Baldwin and Forslid (1996). However, the channel is different as it goes through a direct effect on the cost of innovation and an indirect effect on the spatial distribution of economic activities which further decreases the cost of innovation. Furthermore, the impact is reinforced by the circular causation mechanism at play in our model. 
Graph 5: transaction costs, growth and agglomeration: from= 1.5 to $\tau=1.2$

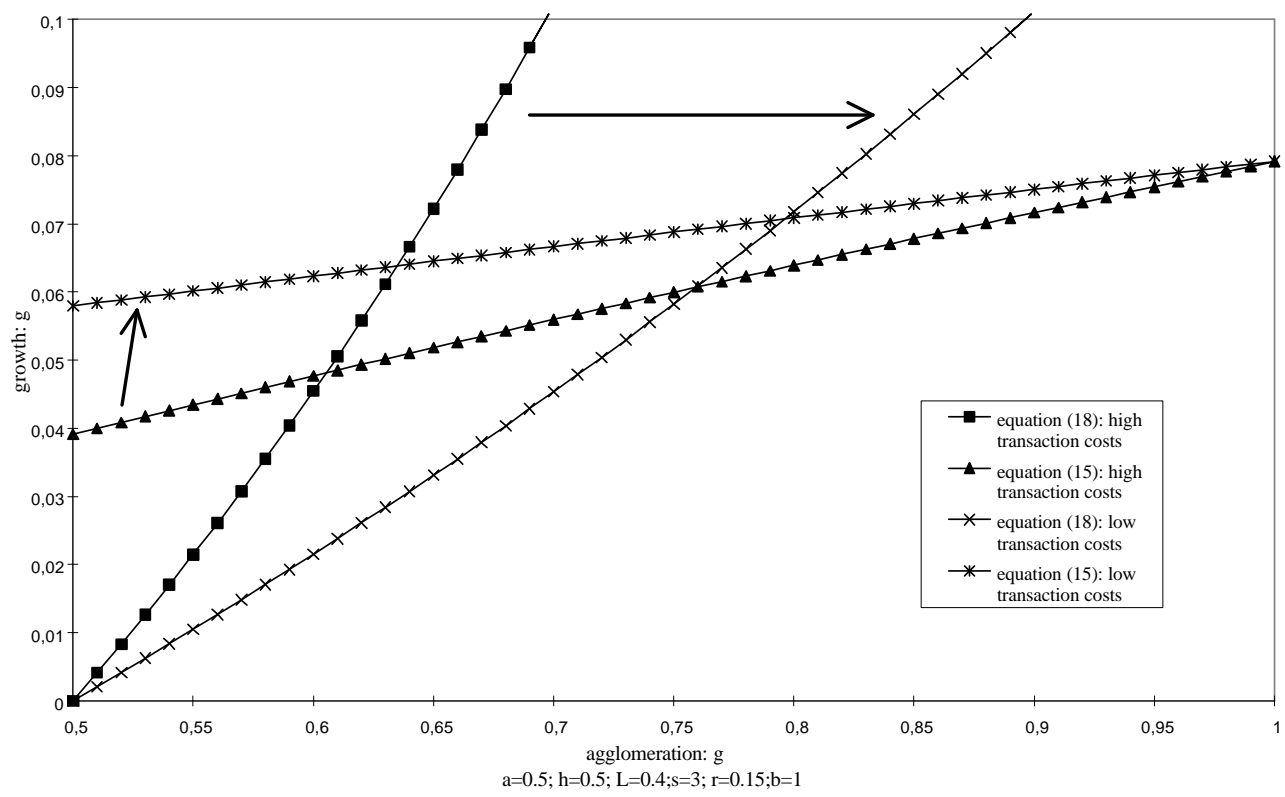

\section{Conclusion}

We have started with two stylized facts: (i) the positive correlation between agglomeration and growth of economic activities ; (ii) the resemblance between the geography of innovation and the geography of production which is best illustrated by the crucial role of cities in both activities. By constructing a model where the growth rate and the geography of innovation and production are jointly determined, we have shown that these two stylized facts come as a natural consequence of the economic forces at work: growth brings agglomeration that fosters growth. For this circular causation mechanism to take place, localized technological spillovers are not required; only market interactions between the innovation sector and the intermediate inputs sector are. Moreover we have shown that the same factors that spur growth also spur agglomeration and the cumulative process that we have identified reinforces the effect that a change of one factor has on both growth and agglomeration. In particular, we have shown that a decrease in transaction costs between regions of an economy encourages both agglomeration and growth of activities for the whole economy.

From a situation where the economy is stagnating and no agglomeration process takes place, a change in the parameters (for example an increase in market size or a decrease in transaction costs following important reforms that make innovation activities more profitable) gives rise to a self-reinforcing mechanism with rapidly increasing growth rates and agglomeration. This circular causation mechanism fits well with the experiences of the industrial revolution in European countries and the urban transition which occurred at the same time as well as the current experience in East Asia. 


\section{APPENDIX: STABILITY CONDITIONS}

When R\&D is fully agglomerated in location 1 , the differential in profits between the two locations depends on the difference between production levels $\mathrm{x}$ and $\mathrm{x}^{*}$ as given in equations (8a-b). The growth rate is given by equation (13), expenditures equal incomes defined by equation (17) and $F$ the cost of $R \& D$ is given by equation (12). We obtain the following equation which gives the differential in profits for a given number of firms as a function of $\gamma$ :

$$
\begin{aligned}
& \mathrm{N}\left(\pi-\pi^{*}\right)=\frac{\alpha \mathrm{L}(1-\delta)^{2}(1-2 \gamma)}{\sigma[\gamma+(1-\gamma) \delta][\delta \gamma+1-\gamma]}+\frac{\alpha \beta \rho \eta(1-\delta)^{2}(1-2 \gamma)[\gamma+(1-\gamma) \delta]^{\frac{\sigma}{1-\sigma}}}{2(\sigma-1)[\delta \gamma+1-\gamma]} \\
& +\frac{2 \alpha \mathrm{L}(1-\delta)}{\sigma(\sigma-1)[\gamma+(1-\gamma) \delta]}-\frac{\rho \eta \beta(1-\delta)(\sigma-\alpha)}{(\sigma-1)^{2}}[\gamma+(1-\gamma) \delta]^{\frac{\sigma}{1-\sigma}}
\end{aligned}
$$

Graph 2 shows that the differential in profits decreases with $\gamma$. As explained in the text, when $\gamma$ is below its equilibrium value, profits in location 1 are higher than in location 2 which induces firms to relocate in 1 . When $\gamma$ is above it the profits are higher in 2 so that firms will relocate in 2 . This also means that the equilibrium is stable as the incentive to relocate in 1 decreases as more firms move there.

Full agglomeration $(\gamma=1)$ is a stable equilibrium for parameters of the model such that the expression above is positive when $\gamma=1$, that is for example when transaction costs are low enough so that:

$$
\delta=\tau^{1-\sigma}>\frac{2 \alpha \mathrm{L}(\sigma-1)^{2}+\alpha \beta \rho \eta \sigma(\sigma-1)}{2 \alpha \mathrm{L}(\sigma-1)(\sigma+1)+\beta \rho \eta \sigma(\alpha \sigma+\alpha-2 \sigma)}
$$

in our numerical example this means that full agglomeration will be a stable equilibrium when the transaction cost parameter $\tau$ is less than 1.123. 


\section{REFERENCES}

- Audretsch, D. B., and M. Feldman, 1996, "R\&D Spillovers and the Geography of Innovation and Production",American Economic Review, volume 86, number 3, 630-640.

- Bairoch, P., 1988, Cities and economic development: from the dawn of history to the present, London Mansell Publ., 1988.

- Baldwin, R. and R. Forslid, 1996, “Trade Liberalization and Endogenous Growth: a qTheory Approach”, CEPR discussion papern ${ }^{\circ} 1397$.

- Dixit, A., J. Stiglitz, 1977, "Monopolistic competition and optimum product diversity", American Economic Review, 67 (2), 297-308.

- Englmann F.C. and U. Walz, 1995, "Industrial Centers and Regional Growth in the Presence of Local Inputs”,Journal of Regional Science, 35, 3-27.

- Flam, H. and E. Helpman, 1987, "Industrial Policy under Monopolistic Competition”, Journal of International Economics vol. 22, 79-102.

- Fujita, M. and J.F. Thisse, 1996, “Economics of Agglomeration”CEPR discussion paper no. 1344 .

- Grossman, G. and E. Helpman, 1991, Innovation and Growth in the World Economy, MIT Press, Cambridge MA.

- Henderson, J. V., 1988, Urban Development, Theory, Fact and Illusion, Oxford, Oxford University Press.

- Hohenberg P. and L.H. Lees, 1985, The Making of Urban Europe (1000-1950), Cambridge, Mass., Harvard University Press.

- Krugman, P., 1991a, Geography and Trade, MIT Press, Cambridge MA. , 1991b, "Increasing returns and economic geography”,Journal of Political Economy, 99, 483-499.

- Kuznets, S., 1966, Modern Economic Growth: Rate, Structure and Spread, Yale University Press.

- Lucas, R. E., 1988, “On the Mechanics of Economic Development,'Journal of Monetary Economics, 22, 3-42.

- Martin P., and G.I.P. Ottaviano, 1996, "Growing Locations: Industry Location in a Model of Endogenous Growth”,CEPR discussion papern ${ }^{\circ} 1523$.

- Martin, P. and C.A. Rogers, 1995, "Industrial location and Public Infrastructure”, Journal of International Economics 39, 1995, 335-51.

- Rivera-Batiz, L. A., and P. Romer, 1991, "Economic Integration and Endogenous Growth", Quarterly Journal of Economics 106, 2, 531-555.

- Romer, P., 1990, “Endogenous Technical Change”,Journal of Political Economy 98, 5, part II, S71-S102. 
- Samuelson, P.,1954, "The Transfer Problem and Transport Costs, II: Analysis of Effects of Trade Impediments," Economic Journal volume LXIV, 264-289.

- Venables, A., 1996, "Equilibrium locations of vertically linked industries"International Economic Review, forthcoming.

-Williamson, J.G., 1988, "Migration and Urbanization", in H. Chenery and T.N.

Srinivasan (eds.), Handbook of Development Economics, volume 1, Amsterdam: North Holland, 425-465.

- Wu, H. X., 1994, "Rural to Urban Migration in the People's Republic of China"The China Quarterly, 669-698. 


\section{LIST OF WORKING PAPERS RELEASED B CEPII ${ }^{14}$}

\section{6}

"La coordination interne et externe des politiques économiques : une analysee dynamique", Fabrice Capoen et Pierre Villa, document de travail n96-13, décembre.

"L'intégration asymétrique au sein du continent américain : un essai de modélisation", Philippine Cour et Frédéric Rupprecht, document de travail $n^{\circ}$ 96-12, octobre.

"Croissance et contrainte financière dans les PED", Pierre Villa, document de travail $n^{\circ}$ 96-11, octobre.

"Bulgaria From Entreprise Indiscipline to Financial Crisis", Roumen Avramov et Jérôme Sgard, document de travail $n^{\circ}$ 96-10,juillet.

"Potentialities and Opportunities of the Euro as an International Currency", Agnès Bénassy-Quéré, document de travailn ${ }^{\circ}$ 96-09, août.

"Credit Crisis and the Role of Banks During Transition: a Five-Country Comparison", Jérôme Sgard, document de travailn ${ }^{\circ}$ 96-08, août.

"Exchange Rate Regimes and Policies in Asia", Agnès Bénassy-Quéré, document de travail $n^{\circ}$ 96-07, juillet.

"France in the Early Depression of the Thirties", Pierre Villadocument de travailn ${ }^{\circ}$ 96-06, juillet.

"Pays émergents, emploi defficient ?", Olivier Cortès et Sébastien Jean, document de travail $n^{\circ}$ 96-05, mars.

"Trade with Emerging Countries and the Labor Market : the French Case", Olivier Cortès, Sébastien Jean et Jean Pisani-Ferry, document de travail n96-04, mars.

"The Transmission of Monetary policy in the European Countries", Fernando Barran, Virginie Coudert et Benoit Mojon, document de travail n96-03, février.

"Trade Policy and Trade Patterns During Transition : A Comparison Between China and CEECs", Françoise Lemoine, document de travail $n^{\circ}$ 96-02 février.

"Financial Markets Failures and Systemic Risk", Michel Aglietta, document de travail $n^{\circ}$ 96-01, janvier

\section{5}

"Why NAFTA Might be Discriminatory", Lionel Fontagnédocument de travail n 95-12 décembre.

"Régionalisation et échanges de biens intermédiaires", Lionel Fontagné, Michael Freudenberg et Deniz Ünal-Kesenci, document de travail $n^{\circ}$ 95-11 décembre.

14 Working papers are circulated free of charge as far as stocks are available; thank you to send your request to CEPII, Sylvie Hurion, 9 rue Georges Pitard, 75015 Paris, or by fax: +33 1535503 . 
"The Geography of Multi-speed Europe", Philippe Martin et Gianmarco I.P Ottaviono, document de travail $n^{\circ} 95-10$, novembre.

"The Political Economy of French Policy and the Transmission to EMU", Christian de Boissieu et Jean Pisani-Ferry, document de travail $n^{\circ}$ 95-09 octobre (épuisé).

"L'importance des exclus de l'intégration monétaire en Europe", Philippe Martin, document de travail $n^{\circ}$ 95-08, novembre.

"Asymétries financières en Europe et transmission de la politique monétaire", Virginie Coudert et Benoit Mojon, document de travail $n^{\circ}$ 95-07 septembre (épuisé).

"La mesure du capital éducatif", Pierre villa,document de travail n95-06, septembre.

"Capital humain, mobilité des capitaux et commerce international", Pierre Villa, document de travail $n^{\circ} 95-05$, juin.

"L'Europe à géométrie variable : une analyse économique", Jean Pisani-Ferry, document de travail $n^{\circ} 95-04$, avril.

"Comparaison de l'efficacité énergétique des pays d'Europe centrale et orientale avec celle des pays de l'OCDE", NinaKounetzoff, document de travail n95-03, mars.

"L'organisation de la politique économique dans un cadre stratégique", Pierre Villa, document de travail $n^{\circ} 95-02$, mars.

"Interest Rates, Banking, Spreads and Credit Supply: The Real Effects", Fernando Barran, Virginie Coudert, Benoît Mojon,document de travail n95-01, mars.

\section{4}

"L'après-CAEM : La dynamique des échanges entre les pays de Visegrad", Dominique Pianelli, document de travail $n^{\circ}$ 94-16, décembre.

"CEEC Export to the EC from 1988 to 1993: Country Differentiation and Commodity Diversification", Françoise Lemoine,document de travail $n^{\circ} 94-15$, décembre.

"Union monétaire et convergence : qu'avons nous appris ?", Jean Pisani-Ferry, document de travail $n^{\circ}$ 94-14, décembre.

"Chômage et salaire en France sur longue période", Pierre Villa, document de travail $n^{\circ}$ 94-13, novembre.

"Croissance et spécialisation", Frédéric Busson et Pierre Villa, d ocument de travail $n^{\circ} 94$ 12, novembre. 
"The International Monetary System: in Search of New Principles", Michel Aglietta, document de travail $n^{\circ} 94-11$, septembre.

"French and German Productivity Levels in Manufacturing : A Comparison Based on the Industry of Origin Method", Deniz Unal-Kesenci et Michael Freudenberg, document de travail $n^{\circ} 94-10$, septembre.

"La réunification allemande du point de vue de la politique économique", Agnès Bénassy et Pierre Villa, document de travail n $94-09$, septembre.

"Commerce international, emploi et salaires", Olivier Cortes et Sébastien Jean, document de travail $n^{\circ}$ 94-08, août.

"La fonction de consommation sur longue période en France", Pierre Villa, document de travail $n^{\circ} 94-07$, juillet.

"Réglementation et prise de risque des intermédiaires financiers : la crise des prix d'actifs au début des années 1990", Benoit Mojondocument de travail n94-06, juillet.

"Turquie : d'une stabilisation à l'autre" Isabelle Bensidoun, document de travail $n^{\circ}$ 94-05, juillet.

"Economic Policy Strategies to Fight Mass Unemployment in Europe: an Appraisal.", Henri Delessy et Henri Sterdyniak,document de travail $n^{\circ}$ 94-04,juillet.

"Transmission de la politique monétaire et crédit bancaire, une application à cinq pays de l'OCDE", Fernando Barran, Virginie Coudert et Benoît Mojon, document de travail n ${ }^{\circ} 94$ 03, juin.

"Indépendance de la banque centrale et politique budgétaire", Agnès Bénassy et Jean Pisani-Ferry, document de travail $n^{\circ} 94-02$, juin.

"Les systèmes de paiements dans l'intégration européenne", Michel Aglietta, document de travail $n^{\circ}$ 94-01, mai. 